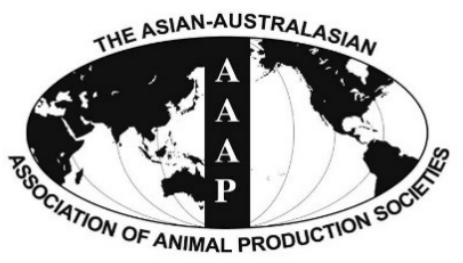

Open Access

Asian Australas. J. Anim. Sci.

Vol. 29, No. 4 : 586-593 April 2016

http://dx.doi.org/10.5713/ajas.15.0507

Www.ajas.info

pISSN 1011-2367 elSSN 1976-5517

\title{
Isolation and Characterization of a New Methanobacterium formicicum KOR-1 from an Anaerobic Digester Using Pig Slurry
}

\author{
Urantulkhuur Battumur, Young-Man Yoon ${ }^{1}$, and Chang-Hyun Kim ${ }^{1,2, *}$ \\ Graduate School of Future Convergence, Hankyong National University, Anseong 456-749, Korea
}

\begin{abstract}
A new methanogen was isolated from an anaerobic digester using pig slurry in South Korea. Only one strain, designated KOR-1, was characterized in detail. Cells of KOR-1 were straight or crooked rods, non-motile, 5 to $15 \mu \mathrm{m}$ long and $0.7 \mu \mathrm{m}$ wide. They stained Gram-positive and produced methane from $\mathrm{H}_{2}+\mathrm{CO}_{2}$ and formate. Strain KOR-1 grew optimally at $38^{\circ} \mathrm{C}$. The optimum pH for growth was 7.0 . The strain grew at $0.5 \%$ to $3.0 \% \mathrm{NaCl}$, with optimum growth at $2.5 \% \mathrm{NaCl}$. The $\mathrm{G}+\mathrm{C}$ content of genomic DNA of strain KOR-1 was $41 \mathrm{~mol} \%$. The strain tolerated ampicillin, penicillin G, kanamycin and streptomycin but tetracycline inhibited cell growth. A large fragment of the $16 \mathrm{~S}$ rRNA gene $(\sim 1,350 \mathrm{bp})$ was obtained from the isolate and sequenced. Comparison of 16S rRNA genes revealed that strain KOR-1 is related to Methanobacterium formicicum (98\%, sequence similarity), Methanobacterium bryantii (95\%) and Methanobacterium ivanovii (93\%). Phylogenetic analysis of the deduced $\mathrm{mcr} A$ gene sequences confirmed the closest relative as based on mcrA gene sequence analysis was Methanobacterium formicicum strain ( $97 \%$ nucleic acid sequence identity). On the basis of physiological and phylogenetic characteristics, strain KOR-1 is proposed as a new strain within the genus Methanobacterium, Methanobacterium formicicum KOR-1. (Key Words: Methanogen, Anaerobic Digester, 16S rRNA, mcrA, Methanobacterium formicicum)
\end{abstract}

\section{INTRODUCTION}

Methanogens are one of the key populations in methanogenic waste and wastewater treatment processes because they are responsible for the final step of the degradation of organic substances (Garcia et al., 2000). They are commonly isolated from natural anoxic environments, including freshwater and marine sediments, wet and waterlogged soils, the rumen and intestinal tract of animals and the gut of insects (Garcia, 1990; Morvan et al., 1996). In addition, molecular surveys targeting the $16 \mathrm{~S}$ rRNA gene and mcrA gene, encoding the alpha subunit of methyl coenzyme $M$ reductase, have revealed that numerous unidentified methanogens may also exist in such

\footnotetext{
* Corresponding Author: Chang-Hyun Kim. Tel: +82-31-6705095, Fax:+82-31-670-5099, E-mail: kimch@hknu.ac.kr

1 Biogas Research Center, Hankyong National University, Anseong 456-749, Korea.

2 Department of Animal Life and Environment Science,

Hankyong National University, Anseong 456-749, Korea.

Submitted Jun. 11, 2015; Revised Jul. 8, 2015; Accepted Jul. 17, 2015
}

ecosystems (Sly et al., 1986; Chouari et al., 2005).

Biological methanogenesis occurs during the anaerobic treatment of sewage sludge, agricultural, municipal and industrial wastes, and manure of cattle, pigs and chickens. This anaerobic digestion process stabilizes the sludge with the formation of methane and offsets the costs of waste disposal. In some urban and industrial waste treatment plants the generated methane is used as an energy source. Anaerobic digestion technology in South Korea has been of greater interest after a ban on ocean dumping of animal manure, sewage sludge and food waste. There are about 49 biogas plants in South Korea that are generally recognized as economically and technically unsuccessful because the existing biogas plants are not running well, produce less methane than expected, or operation costs are very high (Kim et al., 2012). Therefore, there is a need to improve anaerobic digestion technologies, especially understanding microorganisms in anaerobic digesters using biomass such as pig slurry and food waste originally produced in South Korea.

Methanogens are difficult to study through culture- 
based methods, and therefore many researchers have instead used culture-independent techniques such as real-time polymerase chain reaction (qPCR), denaturing gradient gel electrophoresis (DGGE) and sequencing, which have proven to be valuable tools for studying the biodiversity of complex microbial communities such as those in anaerobic digesters (Nettmann et al., 2008; Cardinali-Rezende et al., 2012). To our knowledge, there is no published information available on a methanogen isolated from an anaerobic digester in South Korea. Hence, the present study was aimed to isolate and characterize methanogens responsible for methane production during anaerobic digestion of pig slurry.

\section{MATERIAL AND METHODS}

\section{Source of inoculum}

An anaerobic digestate sample $(2 \mathrm{~L})$ was collected in May 2011 from an anaerobic digester in Biogas Research Center, Hankyong National University, Anseong, Republic of Korea, which was built in early 2008 and kept running for about 4 years. The anaerobic digester had a volume of $150 \mathrm{~m}^{3}$ for anaerobic fermentation and produced $160 \mathrm{~m}^{3}$ biogas per day. The main fermentation substrate was pig slurry from a pig farm breeding 7,000 pigs. The characteristics of the anaerobic digestate in the digester showed the $\mathrm{pH}$ of 8.2 , total volatile fatty acid concentration of 4,500 ppm and chemical oxygen demand of 70,000 ppm. The anaerobic digestate of this digester was used as inoculum for isolation of methanogen.

\section{Medium}

Methanogens are extremely sensitive to oxygen and require strict anoxic condition and pre-reduced media are essential for their growth and isolation. The methods used for the preparation of media and substrate solutions and the cultured techniques were those of Hungate (1950), as modified by Balch et al. (1979). Basal medium for enrichment culture and isolation was prepared with modification as described by Sowers and Schreier (1995) and contained the following compounds (per liter distilled water): $\mathrm{KH}_{2} \mathrm{PO}_{4}, 0.5 \mathrm{~g} ; \mathrm{MgSO}_{4} \cdot 7 \mathrm{H}_{2} \mathrm{O}, 0.4 \mathrm{~g} ; \mathrm{NaCl}, 0.4 \mathrm{~g}$; $\mathrm{NH}_{4} \mathrm{Cl}, 0.4 \mathrm{~g} ; \mathrm{CaCl}_{2} \cdot 2 \mathrm{H}_{2} \mathrm{O}, 0.05 \mathrm{~g} ; \mathrm{FeSO}_{4} \cdot 7 \mathrm{H}_{2} \mathrm{O}, 0.002 \mathrm{~g}$; trace element solution, $1.0 \mathrm{~mL}$; vitamin solution, $10.0 \mathrm{~mL}$; yeast extract, $1.0 \mathrm{~g}$; sodium acetate, $1.0 \mathrm{~g}$; sodium formate, $2.0 \mathrm{~g}$; sludge fluid, $50.0 \mathrm{~mL} ; \mathrm{NaHCO}_{3}, 4.0 \mathrm{~g}$; fatty acid mixture, $20.0 \mathrm{~mL}$; resazurin, $0.001 \mathrm{~g}$; cysteine hydrochloride, $0.5 \mathrm{~g}$; and $\mathrm{Na}_{2} \mathrm{~S} \cdot 9 \mathrm{H}_{2} \mathrm{O}, 0.5 \mathrm{~g}$. The fatty acid mixture contained valeric acid, $0.5 \mathrm{~mL}$; isovaleric acid, 0.5 $\mathrm{mL}$; 2-methylbutyric acid, $0.5 \mathrm{~mL}$; isobutyric acid, $0.5 \mathrm{~mL}$; and distilled water, $20.0 \mathrm{~mL}$, adjusting $\mathrm{pH}$ to 7.5 with concentrated $\mathrm{NaOH}$. The trace element solution was made up of (in one liter of distilled water): nitrilotriacetic acid,
$1.5 \mathrm{~g} ; \mathrm{MgSO}_{4} \cdot \mathrm{H}_{2} \mathrm{O}, 3.0 \mathrm{~g} ; \mathrm{MnSO}_{4} \cdot \mathrm{H}_{2} \mathrm{O}, 0.5 \mathrm{~g} ; \mathrm{NaCl}, 1.0 \mathrm{~g}$; $\mathrm{FeSO} \cdot 7 \mathrm{H}_{2} \mathrm{O}, 0.1 \mathrm{~g} ; \mathrm{CoCl}_{2} \cdot 6 \mathrm{H}_{2} \mathrm{O}, 0.1 \mathrm{~g} ; \mathrm{CaCl}_{2}, 0.1 \mathrm{~g}$; $\mathrm{ZnSO}_{4} \cdot 7 \mathrm{H}_{2} \mathrm{O}, \quad 0.1 \quad \mathrm{~g} ; \quad \mathrm{CuSO}_{4} \cdot 5 \mathrm{H}_{2} \mathrm{O}, \quad 0.01 \mathrm{~g}$; $\mathrm{Al}_{2}\left(\mathrm{SO}_{4}\right)_{3} \cdot 12 \mathrm{H}_{2} \mathrm{O}, 0.01 \mathrm{~g} ; \mathrm{H}_{3} \mathrm{BO}_{3}, 0.01 \mathrm{~g} ; \mathrm{Na}_{2} \mathrm{MoO}_{4} \cdot 2 \mathrm{H}_{2} \mathrm{O}$, $0.01 \mathrm{~g} ; \mathrm{NiSO}_{4} \cdot 6 \mathrm{H}_{2} \mathrm{O}, 0.03 \mathrm{~g} ; \mathrm{Na}_{2} \mathrm{SeO}_{3}, 0.02 \mathrm{~g}$; and $\mathrm{Na}_{2} \mathrm{WO}_{4} \cdot 2 \mathrm{H}_{2} \mathrm{O}, 0.02$ g. Firstly, $1.5 \mathrm{~g}$ nitrilotriacetic acid was added to $500 \mathrm{ml}$ distilled water, adjusting $\mathrm{pH}$ to 6.5 with $\mathrm{KOH}$ and then minerals were added and dissolved making the solution up to a volume of $1,000 \mathrm{~mL}$. The vitamin solution was made up of (in one liter of distilled water): folic acid, $0.01 \mathrm{~g}$; riboflavin, $0.03 \mathrm{~g}$; L-6,8-thioctic acid, $0.03 \mathrm{~g}$; cyanocobalamin, $0.05 \mathrm{~g}$; thiamine chloride hydrochloride, $0.1 \mathrm{~g}$; pyridoxine hydrochloride, $0.15 \mathrm{~g}$; hemicalcium D-(+)-pantothenate, $0.05 \mathrm{~g}$; nicotinic acid, 0.1 g; D-(+)-biotin, $0.01 \mathrm{~g}$; and 4-aminobenzoate, $0.04 \mathrm{~g}$. Clarified sludge fluid was prepared by filtering the anaerobic digestate collected from the anaerobic digester, centrifuging at $13,000 \times \mathrm{g}$ for $30 \mathrm{~min}$, autoclaving at $121^{\circ} \mathrm{C}$ for $20 \mathrm{~min}$ and then recentrifuging to obtain a clear yellow solution. The sludge fluid $(5 \%, \mathrm{v} / \mathrm{v})$ was added as a source of unknown growth factors. The medium was prepared under a $\mathrm{H}_{2} / \mathrm{CO}_{2}(80: 20$, v/v) gas phase at $173 \mathrm{kPa}(25 \mathrm{psi})$. The medium was sterilized by autoclaving at $121^{\circ} \mathrm{C}$ for 30 $\min$.

\section{Enrichment and isolation}

Enrichments were performed in the basal medium adjusted pH 7.0 under the $\mathrm{H}_{2} / \mathrm{CO}_{2}(80: 20$, v/v) gas phase. Vials containing $45 \mathrm{~mL}$ medium were inoculated with $5 \mathrm{~mL}$ inoculum. Benzyl penicillin $\left(2 \times 10^{10} \mathrm{IU} / \mathrm{L}\right)$ and streptomycin sulphate $\left(7 \times 10^{4} \mathrm{IU} / \mathrm{L}\right)$ were added to inhibit the growth of non-methanogenic organisms. The inoculated culture vials were incubated at $38^{\circ} \mathrm{C}$ in the dark for two weeks. A high amount of methane was detected in the culture, and then 5 $\mathrm{mL}$ of the culture was anaerobically transferred into a new vial of sterile basal medium. After four successive transfers, roll tubes containing the basal medium with $1.8 \%$ agar were prepared. Well-isolated colonies were withdrawn with Pasteur pipettes and transferred to culture tubes containing basal medium under anaerobic condition. The culture tubes were sealed with butyl-rubber stoppers and repressurized with sterile filtered $\mathrm{H}_{2} / \mathrm{CO}_{2}(80: 20, \mathrm{v} / \mathrm{v})$ at $173 \mathrm{kPa}(25 \mathrm{psi})$. The organism was re-isolated with the solid basal medium from the liquid cultures. To check the purity of methanogen culture, it was inoculated on bacterial growth medium. The bacterial growth medium was prepared by adding peptone $(2.5 \mathrm{~g} / \mathrm{L})$, yeast extract $(2.5 \mathrm{~g} / \mathrm{L})$, D-glucose $(0.5 \mathrm{~g} / \mathrm{L}), \mathrm{D}$ cellobiose $(0.5 \mathrm{~g} / \mathrm{L})$, D-xylose $(0.5 \mathrm{~g} / \mathrm{L})$ to the basal medium. For the further purification of isolated strain KOR1, a mixture of four antibiotics was used (benzyl penicillin, $0.5 \mathrm{mg} / \mathrm{mL}$; streptomycin sulphate, $0.5 \mathrm{mg} / \mathrm{mL}$; vancomycine- $\mathrm{HCl}, 0.2 \mathrm{mg} / \mathrm{mL}$; and ampicillin, $0.2 \mathrm{mg} / \mathrm{mL}$ ). After purification, the isolate was kept in the basal medium 
without antibiotics. We isolated three methanogens from the isolation process. Strain KOR-1 was microscopically distinguished with rod shape compared with coccal shape of other isolated methanogens. Thus characteristics of the isolated strain KOR-1 were studied at the first.

\section{Physiological studies}

Substrate utilization, growth temperature range, $\mathrm{NaCl}$ concentration range, $\mathrm{pH}$ range, antibiotics tolerance and DNA $\mathrm{G}+\mathrm{C}$ content were investigated for the physiological characteristics of strain KOR-1. Growth was determined by observing optical density (OD) at $660 \mathrm{~nm}\left(\mathrm{OD}_{660}\right)$ with a spectrophotometer (V-530, Jasco, Tokyo, Japan) and measuring the concentration of methane in the gas phase with a gas chromatograph (GC-2010A, Shimadzu, Kyoto, Japan). All experiments for the physiological studies were repeated twice.

The basal medium with acetate and formate omitted, was prepared under $\mathrm{N}_{2}$, and used for substrate-utilization studies. Anaerobic stocks of filter-sterilized substrates (sodium formate, sodium acetate, trimethylamine, methanol, 2-propanol, and isobutanol) were prepared and added separately at final concentrations of $50 \mathrm{mM}$. A freshly grown culture was inoculated at $10 \%(\mathrm{v} / \mathrm{v})$ and vials were incubated at $38^{\circ} \mathrm{C}$ for 20 days. Medium under $\mathrm{H}_{2} / \mathrm{CO}_{2}$ served as the control.

The optimal growth temperature was determined in the basal medium at the optimal $\mathrm{pH}$. Vials inoculated with $10 \%$ $(\mathrm{v} / \mathrm{v})$ culture were incubated at temperatures in the range from $20^{\circ} \mathrm{C}$ to $50^{\circ} \mathrm{C}$. The vials were pressurized every other day with $\mathrm{H}_{2} / \mathrm{CO}_{2}$ to ensure an adequate supply of substrate.

The $\mathrm{pH}$ requirement was determined at the optimum temperature in the basal medium adjusted to $\mathrm{pH}$ values ranging from 4.0 to 9.0. Values above $\mathrm{pH} 4.0$ were produced by adding sterile $\mathrm{Na}_{2} \mathrm{CO}_{3}$ to medium of $\mathrm{pH} 4.0$ until the required value was reached. The $\mathrm{pH} 4.0$ medium was prepared by omitting $\mathrm{NaHCO}_{3}$ from basal medium and cooling it under a $\mathrm{CO}_{2}$ headspace.

Sensitivity of strain KOR-1 to ampicillin, penicillin G, spectromycin, kanamycin, tetracycline and chloramphenicol (all with concentration of $100 \mu \mathrm{g} / \mathrm{mL}$ ) was tested. Five $\mathrm{mL}$ aliquots of the cultures were transferred into fresh medium containing one of the four antibiotics. Strain KOR-1 was incubated for 1 week at $38^{\circ} \mathrm{C}$. The impact of antibiotics was determined by comparing the growth of cultures containing these antibiotics with control.

The salinity range of the isolate was tested at $\mathrm{NaCl}$ concentrations from $0.5 \%$ to $3.0 \% \mathrm{NaCl}$ at $0.5 \%$ intervals. Media with various concentrations of $\mathrm{NaCl}$ were prepared by adding sterile anoxic stock solution of $58.44 \mathrm{~g} / \mathrm{L} \mathrm{NaCl}$ to medium.

\section{Microscopy}

An Olympus BX41 phase-contrast microscope (Olympus, Tokyo, Japan) was used routinely to observe cells. The Gram character was determined using a standard Gram-stain kit (BBL Microbiology Systems, Becton Dickinson, Bergen County, NJ, USA). Motility was determined by the hanging-drop method, using a glass cavity slide.

\section{DNA extraction and $\mathbf{G}+\mathbf{C}$ content}

Culture samples of strain KOR-1 grown with the basal medium were used for DNA isolation (FastDNA SPIN kit for soil, MP Biomedicals, Irvine, CA, USA) and following the manufacturer's instructions. DNA integrity was checked on $1 \%$ agarose gel and DNA concentration was determined using Nanodrop (ND 2000, Thermo Fisher Scientific, Waltham, MA, USA). The DNA G+C content was determined from thermal denaturation profiles (Sly et al., 1986). The experiments for the DNA extraction and $\mathrm{G}+\mathrm{C}$ content of strain KOR-1 were conducted several times until to get clear results.

\section{PCR amplification of 16S rRNA genes}

16S rRNA gene amplicons $(\sim 1,350 \mathrm{bp})$ were obtained using the following primer pair: Ar109f (5, ACKGCTCAGTAACACGT-3') (Großkopf et al., 1998) and Ar1383r (5'-CGGTGTGTGCAAGGAGCA-3') (Shlimon et al., 2004). Reaction mixtures contained the following components in a final volume of $20 \mu \mathrm{L}$ in a 200 $\mu \mathrm{L}$ PCR reaction tube: $2 \mu \mathrm{L}$ PCR reaction buffer (Takara, Tokyo, Japan), $2 \mu \mathrm{L}$ dNTP mix (35 mM), $0.5 \mu \mathrm{L}$ each primer $(10 \mathrm{pmol} / \mu \mathrm{L}), 0.1 \mu \mathrm{L}$ Taq DNA polymerase (Takara, Japan), $1.0 \mu \mathrm{L}$ template DNA sample (100 ng) and $13.9 \mu \mathrm{L}$ molecular grade water (Severn Biotech Ltd, Kidderminster, Worcester, UK). The PCRs were started by immediately placing the reaction tubes into the preheated $\left(94^{\circ} \mathrm{C}\right)$ thermal cycler (PCR Thermal Cycler Dice, Takara, Japan). The thermal program was as follows: an initial denaturation step $\left(94^{\circ} \mathrm{C}, 4 \mathrm{~min}\right)$ was followed by 30 cycles of denaturation $\left(94^{\circ} \mathrm{C}, 30 \mathrm{~s}\right)$, annealing $\left(55^{\circ} \mathrm{C}, 30 \mathrm{~s}\right)$ and extension $\left(72^{\circ} \mathrm{C}\right.$, $90 \mathrm{~s})$. After a final extension step $\left(72^{\circ} \mathrm{C}, 6 \mathrm{~min}\right)$ samples were kept at $4^{\circ} \mathrm{C}$ until further analysis. Each PCR run included a positive control using DNA extracted from pure cultures and a negative PCR control where molecular grade water was substituted for the DNA template. The DNA product was analyzed using gel electrophoresis $(1.2 \% \mathrm{w} / \mathrm{v}$ agarose gel stained and run at $100 \mathrm{~V}$ for $30 \mathrm{~min}$ in $1 \times$ Trisacetate-ethylene-diamine-tetracetic acid (TAE) buffer with $5 \mu \mathrm{L}$ aliquots of each DNA product. The TAE buffer was composed of $40 \mathrm{mM}$ Tirs base, $20 \mathrm{mM}$ acetic acid and 0.5 $\mathrm{M}$ ethylene-diamine-tetracetic acid (EDTA) ( $\mathrm{pH} \mathrm{8.0).} \mathrm{The}$ gel was run with $2.5 \mu \mathrm{L}$ Ladder I DNA quantification 
marker (TNTresearch, Seoul, Korea). The gel was imaged using Bio Imaging System (Daihan, Seoul, Korea) and photograph was taken using WiseCapture II software (Daihan, Korea).

\section{PCR amplification of $\boldsymbol{m c r} A$ genes}

The mcrA genes fragments were amplified using the primer combinations MLf (5'- GGTGGTGTMGGATTC ACACARTAYGCWACAGC-3') and MLr (5'-TTCA TTGCRTAGTTWGGRTAGTT-3'), yielding $\sim 490$ bp amplicons (Luton et al., 2002), ME1 (5'-GCMAT GCARATHGGWATGTC-3') and ME2 (5'-TCATKGCRTA GTTDGGRTAGT-3'), yielding 740 bp amplicons (Hales et al., 1996), and MR1 (5'-GACCTCCACTWCGT VAACAACGC-3') and ME2, yielding amplicons of $\sim 1,100$ bp (Simankova et al., 2003). Denaturation, annealing and extension were carried out at $96^{\circ} \mathrm{C}(15 \mathrm{~s}), 55^{\circ} \mathrm{C}(30 \mathrm{~s})$ and $72^{\circ} \mathrm{C}$ (90 s), respectively, with MLf/MLr primers, and $94^{\circ} \mathrm{C}$ $(40 \mathrm{~s}), 50^{\circ} \mathrm{C}(45 \mathrm{~s})$ and $72^{\circ} \mathrm{C}(90 \mathrm{~s})$, respectively, with $\mathrm{ME} 1 / \mathrm{ME} 2$ primers and MR1/ME2 primers.

\section{Phylogenetic and sequencing analysis}

PCR products were purified with the AccuPrep PCR purification kit (Bioneer, Daejeon, Korea). Sequencing of PCR products was performed using the BigDye terminator cycle sequencing kit on ABI 3730XL capillary DNA Sequencer (Applied Biosystems, Thermo Fisher Scientific Inc., Carlsbad, CA, USA). 16S rRNA and mcrA genes sequences of strain KOR-1 were compared with the other similar sequences obtained from GenBank using the BLAST program. Phylogenetic analysis was conducted in MEGA 4.0 (Tamura et al., 2007). Eight additional 16S rRNA sequences (Methanobacterium formicicum [NR025028]; Methanobacterium subterraneum [NR028247]; Methanobacterium palustre [NR041713]; Methanobacterium alcaliphilum [NR028228]; Methanobacterium bryantii [NR042781]; Methanobacterium oryzae [NR028171]; Methanobacterium ivanovii [NR041716]; Methanosphaera stadtmanae [NR028236]) representing methanogens were included in phylogenetic analysis. Phylogeny was further confirmed by mcrA gene and mcrA protein sequences (Methanobacterium formicicum [EF465103]; Methanobacterium palustre [AB542760]; Methanobacterium kanagiense [AB551870]; Methanobacterium bryantii [AF313806]; Methanobacterium aarhusense [AY386125]; Methanopyrus kandleri [U57340]).

\section{Nucleotide sequence accession number}

The 16S rRNA, mcrA gene and mcrA amino acid sequences of strain KOR-1 determined in this study have been deposited in the GenBank database under No JQ973735, JX141395, and AFP23434.

\section{RESULT AND DISCUSSION}

\section{Characterization of the isolated methanogen}

A new methanogen was isolated from an anaerobic digester using pig slurry from Anseong, South of Korea. The methanogenic enrichment culture dominated by long rods was obtained after two months. Visible colonies in agar tubes appeared after three weeks of incubation at $38^{\circ} \mathrm{C}$. Surface colonies were about $2 \mathrm{~mm}$ in diameter, yellow, circular and concave after three weeks incubation. Only one strain, designated KOR-1, was characterized in detail.

Table 1 shows phenotype and growth characteristics of strain KOR-1 comparing with Methanobacterium formicicum DSM1535 ${ }^{\mathrm{T}}$ (Bryant and Boone, 1987) and Methanobacterium bryantii DSM $863^{\mathrm{T}}$ (Bryant et al., 1967;

Table 1. Comparative characteristics of strain KOR-1, Methanobacterium formicicum DSM1535 $5^{\mathrm{T}}$ and Methanobacterium bryantii DSM $863^{\mathrm{T}}$

\begin{tabular}{|c|c|c|c|}
\hline$\overline{\text { Characteristics }}$ & KOR-1 & DSM1535 & DSM863 $^{\mathrm{T}}$ \\
\hline Gram staining & + & + & Variable \\
\hline Cell morphology & Rod & Rod & Rod \\
\hline Cell width $(\mu \mathrm{m})$ & 0.7 & $0.4-0.8$ & $0.5-1.0$ \\
\hline Cell length $(\mu \mathrm{m})$ & $5.0-15.0$ & $2.0-15.0$ & $10.0-15.0$ \\
\hline \multicolumn{4}{|l|}{ Temperature for growth $\left({ }^{\circ} \mathrm{C}\right)$} \\
\hline Range & $25-50$ & ND & $20-50$ \\
\hline Optimum & 38 & $37-45$ & 37 \\
\hline \multicolumn{4}{|l|}{$\mathrm{pH}$ for growth } \\
\hline Range & $6.0-8.3$ & ND & $5.8-8.8$ \\
\hline Optimum & 7.0 & $6.6-7.8$ & $6.9-7.0$ \\
\hline \multicolumn{4}{|l|}{$\mathrm{NaCl}$ for growth range (\%) } \\
\hline Range & $0.5-3.0$ & ND & $0.0-1.6$ \\
\hline Optimum & 2.5 & ND & ND \\
\hline DNA G $+\mathrm{C}$ content $(\mathrm{mol} \%)^{1}$ & $41\left(T_{\mathrm{m}}\right)$ & $41-42(\mathrm{Bd})$ & $32.7\left(T_{\mathrm{m}}\right)$ \\
\hline \multicolumn{4}{|l|}{ Substrate utilization } \\
\hline $\mathrm{H}_{2} / \mathrm{CO}_{2}$ & + & + & + \\
\hline Formate & + & + & - \\
\hline Acetate & - & - & - \\
\hline Methanol & - & - & - \\
\hline Trimethylamine & - & - & - \\
\hline 2-propanol & - & - & + \\
\hline Isobutanol & - & - & + \\
\hline \multicolumn{4}{|l|}{ Tolerance for antibiotics } \\
\hline Ampicillin & + & ND & ND \\
\hline Penicillin G & + & ND & ND \\
\hline Spectromycin & + & ND & ND \\
\hline Kanamycin & + & ND & ND \\
\hline Tetracycline & - & ND & ND \\
\hline Chloramphenicol & \pm & ND & ND \\
\hline
\end{tabular}

-, negative; + , positive; ND, no data available.

Data for strain KOR-1 were from this study, and strain DSM $1535^{\mathrm{T}}$ were retrieved from Bryant and Boone (1987) and DSM 863 ${ }^{\mathrm{T}}$ were from Bryant et al. (1967) and Boone (1987).

${ }^{1}$ Determined by buoyant density analysis $(\mathrm{Bd})$ and Melting point analysis $\left(T_{\mathrm{m}}\right)$ 
Boone, 1987). The isolate was phenotypically similar to the compared species of Methanobacterium. Cells of KOR-1 were straight or crooked rods, non-motile, 5.0 to $15.0 \mu \mathrm{m}$ long and $0.7 \mu \mathrm{m}$ wide. They stained Gram-positive (Figure 1). In liquid cultures, cells of KOR-1 often attached to particles, forming clumps. Along with Methanobacterium formicicum DSM1535 $5^{\mathrm{T}}$ and Methanobacterium bryantii DSM $863^{\mathrm{T}}$, strain KOR-1 demonstrated wide growth temperature and $\mathrm{pH}$ ranges. Growth of strain KOR-1 was observed in the temperature range of $25^{\circ} \mathrm{C}$ to $50^{\circ} \mathrm{C}$, with fastest growth at $38^{\circ} \mathrm{C}$. Most strains in the genus Methanobacterium are mesophilic and grow in a wide range of temperature from $3{ }^{\circ} \mathrm{C}$ to $50^{\circ} \mathrm{C}$ (Krivushin et al., 2010) but not at $55^{\circ} \mathrm{C}$ (Joulian et al., 2000; Boone, 2001), distinguishing them from the related thermophilic genus, Methanothermobacter (Wasserfallen et al., 2000). The optimum $\mathrm{pH}$ for growth was 7.0 for strain KOR-1. No growth occurred below pH 6.0 or above 8.3. The optimum $\mathrm{pH}$ for growth of strain KOR-1 (pH 7.0) is similar to those of Methanobacterium formicicum (pH 6.6 to 7.8) (Bryant and Boone, 1987) and Methanobacterium congolense ( $\mathrm{pH}$ 7.2) (Cuzin et al., 2001) and slight different from those of Methanobacterium subterraneum ( $\mathrm{pH} \quad 7.8$ to 8.8) (Kotelnikova et al., 1998), Methanobacterium alcaliphilum ( $\mathrm{pH} 8.1$ to 9.1) (Worakit et al., 1986) and Methanobacterium espanolae (pH 5.6 to 6.2) (Patel et al., 1990). The growth range for $\mathrm{pH}$ of strain KOR-1 falls within the range that has been reported for the genus Methanobacterium (Krivushin et al., 2010). Strain KOR-1 grew at $\mathrm{NaCl}$ concentrations of $0.5 \%$ to $3.0 \%$, with optimum growth at $2.5 \% \mathrm{NaCl}$. The range is typical for a halotolerant organism.

Strain KOR-1 used $\mathrm{H}_{2} / \mathrm{CO}_{2}$ and sodium formate (50

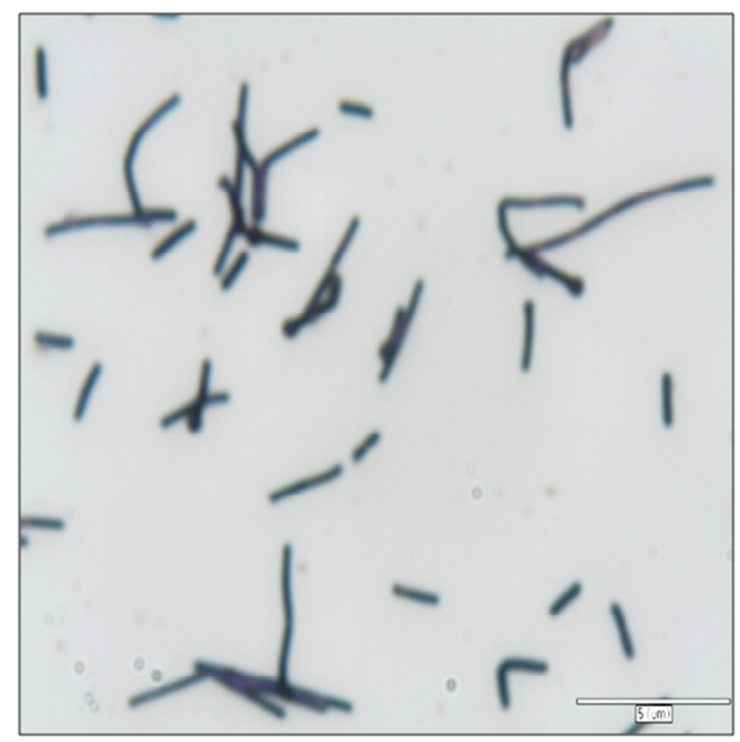

Figure 1. Phase-contrast microscopy of strain KOR-1. Bar indicates $5 \mu \mathrm{m}$.
$\mathrm{mM}$ ) to produce methane. Under a $\mathrm{N}_{2}: \mathrm{CO}_{2}(4: 1)$ atmosphere, strain KOR-1 could not produce methane from sodium acetate $(50 \mathrm{mM})$, trimethylamine $(50 \mathrm{mM})$, methanol $(50$ $\mathrm{mM})$, 2-propanol $(50 \mathrm{mM})$ or isobutanol $(50 \mathrm{mM})$. The substrate utilization for methanogenesis of strain KOR-1 is similar to that of Methanobacterium formicicum DSM1535 (Bryant and Boon, 1987), while Methanobacterium bryantii DSM863 ${ }^{\mathrm{T}}$ utilized 2-propanol and isobutanol as hydrogen donors for the reduction of $\mathrm{CO}$ to produce methane in addition to $\mathrm{H}_{2} / \mathrm{CO}_{2}$ (Bryant et al., 1967; Boone, 1987). Strain KOR-1 shared phenotypic characteristics of the strain DSM1535 of Methanobacterium formicicum isolated from digester sludge but had a growth requirement for sludge fluid or yeast extract, a characteristic not found in the type strain. Strain KOR-1 is also similar to Methaonbacterium oryzae DSM $11106^{\mathrm{T}}$ (Joulian et al., 2000) and Methanobacterium beijingense DSM $15999^{\mathrm{T}}$ (Ma et al., 2005), both of which can use $\mathrm{H}_{2} / \mathrm{CO}_{2}$ and formate for growth, requiring yeast extract. Thus, the growth of strain KOR-1 is common among members of the genus Methanobacterium, considering the strain as chemoautotrophic (Boone, 2001).

The strain tolerated ampicillin, penicillin $\mathrm{G}$, kanamycin and streptomycin and was sensitive to chloramphenicol. However, tetracycline completely inhibited cell growth. Tetracycline is related to inhibition of translation during protein biosynthesis. Hilpert et al. (1981) reported that tetracycline inhibited growth of Methanococcus vannielii, but most methanogens tested were insensitive. Chopra and Howe (1978) reported that methanogens used in their study were insensitive to tetracycline because the growth medium used contained high magnesium. They indicated that the tetracycline susceptibility of certain Gram-negative bacteria was decreased as the concentration of magnesium in a medium is increased, probably through the formation of antibiotic-cation complexes. The basal medium for the growth of strain KOR-1 containing $3.0 \mathrm{mg} \mathrm{MgSO}_{4} / \mathrm{L}$ medium may not be enough to decrease its susceptibility to tetracycline. Whitman et al. (2014) reported that members of the genus Methanobacterium may possess a particulate dehydrogenase enzyme that is sensitive to chloramphenicol.

The $\mathrm{G}+\mathrm{C}$ content of genomic DNA of strain KOR-1 was $41 \mathrm{~mol} \%$. This value is similar to Methanobacterium formicicum DSM1535 ${ }^{\mathrm{T}}$ (Bryant and Boone, 1987), but higher than Methanobacterium bryantii DSM863 ${ }^{\mathrm{T}}$ (Bryant et al., 1967; Boone, 1987). The family Methanobacteriaceae has a wide range of the $\mathrm{mol} \% \mathrm{G}+\mathrm{C}$ of the DNA between 23 and 62 (Oren, 2014).

\section{Molecular characterization}

PCR based on 16S rRNA gave an amplicon size of 1,350 bp (Figure 2a). The identification was also confirmed by mcrA gene-based amplification using MLf and MLr 


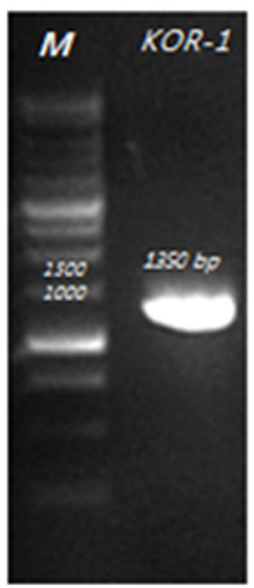

A

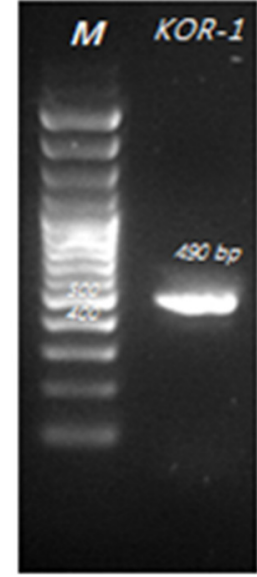

B

Figure 2. Agarose gel electrophoresis of PCR products of strain KOR-1 (A: 16S rRNA gene and B: $m c r A$ gene).

primers that resulted in product size of 440 to $490 \mathrm{bp}$ (Figure 2a). A large fragment of the 16S rRNA gene $(\sim 1,350 \mathrm{bp})$ was obtained from the isolate and sequenced. Comparative 16S rRNA gene sequence analysis showed that strain KOR-1 was affiliated with the order Methanobacteriales. The closest relatives of strain KOR-1 were Methanobacterium formicicum $(98 \%$, sequence similarity), Methanobacterium bryantii $(95 \%)$ and Methanobacterium ivanovii (Figure 3). For PCR amplification of the $m c r$ A gene, we used primers ME1/ME2 (Hales et al., 1996) and MR1/ME2 (Simankova et al., 2003) to obtain the nearly full-length $m c r$ A gene. The $m c r$ A gene sequence also indicated that strain KOR-1 was a member of the order Methanobacteriales. The closest relatives on the bases on the mcrA gene sequence were Methanobacterium

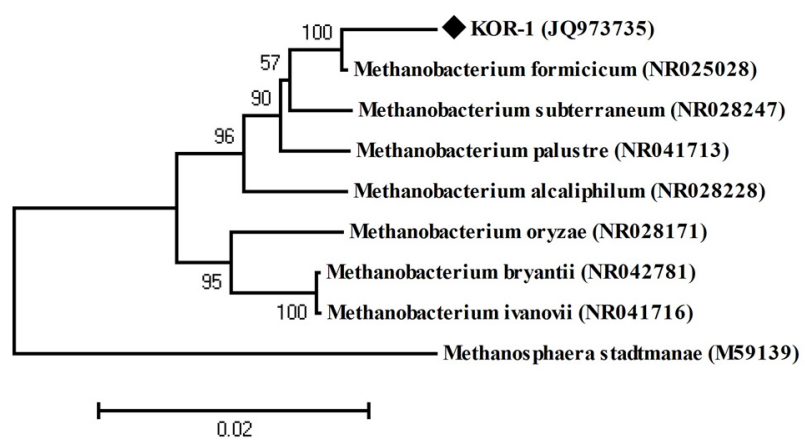

Figure 3. Phylogenetic dendrogram of $16 \mathrm{~S}$ rRNA gene sequences showing the position of Methanobacterium formicicum strain KOR-1 relative to other species of the genus Methanobacterium as well as selected reference sequences of methanogens. Methanosphaera stadtmanae was used as outgroup references. The evolutionary distances were computed using the maximum composite likelihood method (Tamura et al., 2007). Bootstrap values are shown at nodes (percentages of 500 replicates). GenBank accession numbers are indicated. A bar represents 0.02 substitutions per nucleotide position.

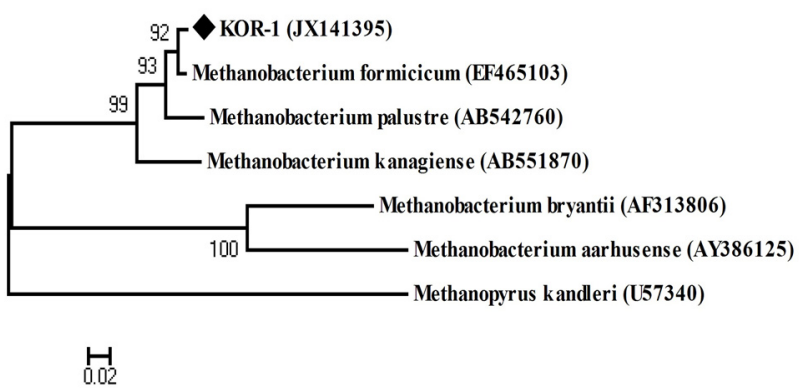

Figure 4. Phylogenetic tree of deduced $m c r$ A genes sequences indicating the relationship of Methanobacterium formicicum strain KOR-1 to members of the genus Methanobacterium and other methanogenic archaea. Methanopyrus kandleri was used as outgroup references. GenBank accession numbers are indicated. Bootstrap values are shown at nodes (percentages of 500 replicates). A bar represents 0.02 substitutions per nucleotide position.

formicicum (97\%) and Methanobacterium palustre (94\%). In addition, we determined the sequence part of $\mathrm{mcr}$ A gene (440 to $490 \mathrm{bp}$ ) and then constructed a molecular phylogenetic tree based on methyl-coenzyme $\mathrm{M}$ reductase II alpha subunit sequences of $m c r \mathrm{~A}$ gene. The $m c r \mathrm{~A}$ gene sequence-based tree also indicated that strain KOR-1 was a member of the order Methanobacteriales. The closest relative as based on $m c r$ A gene sequence analysis was Methanobacterium formicicum strain $(97 \%$ nucleic acid sequence identity) (Figure 4). No major differences were observed between DNA and amino acid sequences or between the different algorithms used (Figures 3 to 5). The phylogenetic tree with 16S rRNA gene (Figure 3) sequences showed two major clusters: cluster 1 and 2, which were entirely different from each other. Cluster 1 contained 2 sub clusters: with KOR-1 in sub cluster 1 that showed 100\% similarity with Methanobacterium formicicum (NR025028). $m c r$ A gene (Figure 4) and amino acid sequences (Figure 5)

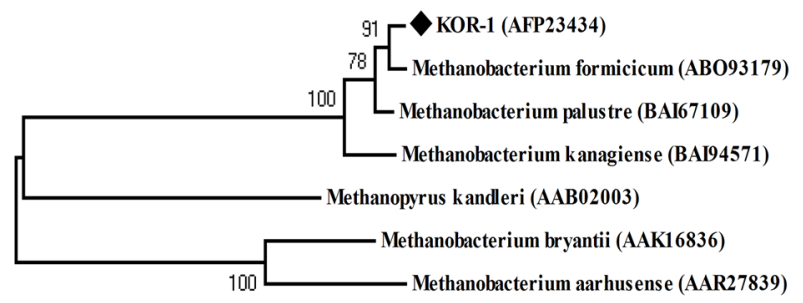

$$
\stackrel{0.1}{0.02}
$$

Figure 5. Phylogenetic tree of deduced $m c r \mathrm{~A}$ amino acid sequences showing the relationship of Methanobacterium formicicum KOR-1 with related methanogenic archaea. The tree was constructed based on distance matrices (154 amino acid positions; Poisson correction) by the neighbor-joining method. The sequence of Methanopyrus kandleri was used as the outgroup reference. Accession numbers are shown in parentheses. A bar represents 0.02 substitutions per nucleotide position. 
showed three major clusters: cluster 1 contained 3 sub clusters with KOR-1 in sub cluster 1 that showed 99\% similarity with Methanobacterium formicicum. All three showed similar phylogenetic results and thus are in accordance with Luton et al. (2002) who stated that $\mathrm{mcrA}$ gene sequence can be used an alternative to $16 \mathrm{~S}$ rRNA based sequences.

On the basis of physiological and phylogenetic differences, strain KOR-1 was proposed as a new strain within the genus Methanobacterium, Methanobacterium formicicum KOR-1.

\section{CONFLICT OF INTEREST}

We certify that there is no conflict of interest with any financial organization regarding the material discussed in the manuscript.

\section{ACKNOWLEDGMENTS}

This work was supported by a research grant from Hankyong National University for an academic exchange program in 2014.

\section{REFERENCES}

Balch, W. E., G. E. Fox, L. J. Magrum, C. R. Woese, and R. S. Wolfe. 1979. Methanogens: Reevaluation of a unique biological group. Microbiol. Rev. 43:260-296.

Boone, D. R. 1987. Request for an opinion: Replacement of the type strain of Methanobacterium formicicum and reinstatement of Methanobacterium bryantii sp. nov. nom. rev. (ex Balch and Wolfe, 1981) with M.o.H. (DSM 863) as the type strain. Int. J. Syst. Evol. Microbiol. 37:172-173.

Boone, D. R. 2001. Genus I. Methanobacterium. In: Bergey's Manual of Systematic Bacteriology, 2nd Ed. Vol 1 (Eds. D. R. Boone and R. W. Castenholz). Springer, New York, USA. pp. 215-218.

Bryant, M. P. and D. R. Boone. 1987. Isolation and characterization of Methanobacterium formicicum MF. Int. J. Syst. Evol. Microbiol. 37:171.

Bryant, M. P., E. A. Wolin, M. J. Wolin, and R. S. Wolfe. 1967. Methanobacillus omelianskii, a symbiotic association of two species of bacteria. Arch. Mikrobiol. 59:20-31.

Cardinali-Rezende, J., L. F. D. B. Colturato, T. D. B. Colturato, E. Chartone-Souza, A. M. A. Nascimento, and J. L. Sanz. 2012. Prokaryotic diversity and dynamics in a full-scale municipal solid waste anaerobic reactor from start-up to steady-state conditions. Bioresour. Technol. 119:373-383.

Chopra, I. and T. G. B. Howe. 1978. Bacterial resistance to the tetracyclines. Microbiol. Rev. 42:707-724.

Chouari, R., D. Le Paslier, P. Daegelen, P. Ginestet, J. Weissenbach, and A. Sghir. 2005. Novel predominant archaeal and bacterial groups revealed by molecular analysis of an anaerobic sludge digester. Environ. Microbiol. 7:1104-1115.

Cuzin, N., A. S. Ouattara, M. Labat, and J.-L. Garcia. 2001.
Methanobacterium congolense sp. nov., from a methanogenic fermentation of cassava peel. Int. J. Syst. Evol. Microbiol. 51: 489-493.

Garcia, J.-L. 1990. Taxonomy and ecology of methanogens. FEMS Micobiol. Rev. 87:297-308.

Garcia, J.-L., B. K. C. Patel, and B. Ollivier. 2000. Taxonomic, phylogenetic, and ecological diversity of methanogenic archaea. Anaerobe 6:205-226.

Großkopf, R., P. H. Janssen, and W. Liesack. 1998. Diversity and structure of the methanogenic community in anoxic rice paddy soil microcosms as examined by cultivation and direct $16 \mathrm{~S}$ rRNA gene sequence retrieval. Appl. Environ. Microbiol. 64: 960-969.

Hales, B. A., C. Edwards, D. A. Ritchie, G. Hall, R. W. Pickup, and J. R. Saunders. 1996. Isolation and identification of methanogen-specific DNA from blanket bog peat by PCR amplification and sequence analysis. Appl. Environ. Microbiol. 62:668-675.

Hilpert, R., J. Winter, W. Hammes, and O. Kandler. 1981. The sensitivity of archaebacteria to antibiotics. Zbl. Bakt. Hyg. I. Abt. Orig. 2:11-20.

Hungate, R. E. 1950. The anaerobic mesophilic cellulolytic bacteria. Bacteriol. Rev. 14:1-49.

Joulian, C. J., B. K. C. Patel, B. Ollivier, J.-L. Garcia, and P. A. Roger. 2000. Methanobacterium oryzae sp. nov., a novel methanogenic rod isolated from a Philippines ricefield. Int. J. Syst. Evol. Microbiol. 50:525-528.

Kim, Y.-S., Y.-M. Yoon, C.-H. Kim and J. Giersdort. 2012. Status of biogas technologies and policies in South Korea. Renew. Sustain. Energy Rev. 16:3430-3438.

Kotelnikova, S., A. J. L. Macario, and K. Pedersen. 1998. Methanobacterium subterraneum sp. nov., a new alkaliphilic, eurythermic and halotolerant methanogen isolated from deep granitic groundwater. Int. J. Syst. Evol. Microbiol. 48:357-367.

Krivushin, K. V., V. A. Shcherbakova, L. E. Petrovskaya, and E. M. Rivkina. 2010. Methanobacterium veterum sp. nov., from ancient Siberian permafrost. Int. J. Syst. Evol. Microbiol. 60: 455-459.

Luton, P. E., J. M. Wayne, R. J. Sharp, and P. W. Riley. 2002. The mcrA gene as an alternative to $16 \mathrm{~S}$ rRNA in the phylogenetic analysis of methanogen populations in landfill. Microbiology 148:3521-3530.

Ma, K., X. Liu, and X. Dong. 2005. Methanobacterium beijingense sp. nov., a novel methanogen isolated from anaerobic digesters. Int. J. Syst. Evol. Microbiol. 55:325-329.

Morvan, B., F. Bonnemoy, G. Fonty, and P. Gouet. 1996. Quantitative determination of $\mathrm{H}_{2}$-utilizing acetogenic and sulfate-reducing bacteria and methanogenic archaea from digestive tract of different mammals. Curr. Microbiol. 32:129133 .

Nettmann, E., I. Bergmann, K. Mundt, B. Linke, and M. Klocke. 2008. Archaea diversity within a commercial biogas plant utilizing herbal biomass determined by $16 \mathrm{~S}$ rDNA and $\mathrm{mcr} A$ analysis. J. Appl. Microbiol. 105:1835-1850.

Oren, A. 2014. The family Methanobacteriaceae. In: The Prokaryotes: Other Major Lineages of Bacteria and the Archaea (Eds. E. Rosenberg, E. F. DeLong, S. Lory, E. Stackebrandt, and F. Thompson). Springer, Berlin, Germany. pp. 165-193. 
Patel, G. B., G. D. Sprott, and J. E. Fein. 1990. Isolation and characterization of Methanobacterium espanolae sp. nov., a mesophilic, moderately acidiphilic methanogen. Int. J. Syst. Bacteriol. 40:12-18.

Shlimon, A. G., M. W. Friedrich, H. Niemann, N. B. Ramsing, and K. Finster. 2004. Methanobacterium aarhusense sp. nov., a novel methanogen isolated from a marine sediment (Aarhus Bay, Denmark). Int. J. Syst. Evol. Microbiol. 54:759-763.

Simankova, M. V., O. R. Kotsyurbenko, T. Lueders, A. N. Nozhevnikova, B. Wagner, R. Conrad, and M. W. Friedrich. 2003. Isolation and characterization of new strains of methanogens from cold terrestrial habitats. Syst. Appl. Microbiol. 26:312-318.

Sly, L. I., L. L. Blackall, P. C. Kraat, T. Tian-Shen, and V. Sangkhobol. 1986. The use of second derivative plots for the determination of mol\% guanine plus cytosine of DNA by the thermal denaturation method. J. Microbiol. Methods 5:139-156.

Sowers, K. R. and H. J. Schreier. 1995. Media for methanogens. In: Archaea - A Laboratory Manual: Methanogens (Eds. K. R. Sowers and H. J. Schreier). Cold Spring Harbor Laboratory Press, New York, USA. pp. 459-489.
Tamura, K., J. Dudley, M. Nei, and S. Kumar. 2007. MEGA4: molecular evolutionary genetics analysis (MEGA) software version 4.0. Mol. Biol. Evol. 24:1596-1599.

Wasserfallen, A., J. Nolling, P. Pfister, J. Reeve, and E. Conway de Macario. 2000. Phylogenetic analysis of 18 thermophilic Methanobacterium isolates supports the proposals to create a new genus, Methanothermobacter gen. nov., and to reclassify several isolates in three species, Methanothermobacter thermautotrophicus comb. nov., Methanothermobacter wolfeii comb. nov., and Methanothermobacter marburgensis sp. nov. Int. J. Syst. Evol. Microbiol. 50:43-53.

Whitman, W. B., T. L. Bowen, and D. R. Boone. 2014. The methanogenic bacteria. In: The Prokaryotes: Other Major Lineages of Bacteria and the Archaea (Eds. E. Rosenberg, E. F. DeLong, S. Lory, E. Stackebrandt, and F. Thompson). Springer, Berlin, Germany. pp. 123-164.

Worakit, S., D. R. Boone, R. A. Mah, M.-E. Abdel-Samie, and M. M. El-Halwagi. 1986. Methanobacterium alcaliphilum sp. nov., an $\mathrm{H}_{2}$-utilizing methanogen that grows at high $\mathrm{pH}$ values. Int. J. Syst. Bacteriol. 36:380-382. 